\title{
IDENTYFIKACJA PRAKTYCZNYCH OBSZARÓW ZASTOSOWANIA MODELI EKONOFIZYCZNYCH
}

\author{
Piotr Młodzianowski \\ Politechnika Warszawska \\ Wydział Zarządzania
}

\begin{abstract}
Streszczenie: W artykule zaprezentowano wyniki rozważań nad praktycznym zastosowaniem modeli ekonofizycznych w różnych obszarach i zakresach wspomagania zarządzania. Przybliżono w nim wykorzystywane w naukach ekonomicznych i społecznych modele grawitacyjne i gier mniejszościowych. Przedstawiono ich zastosowanie w takich obszarach jak handel, transport, badanie fluktuacji na rynkach finansowych czy podejmowania decyzji. Podjęto próbę określenia białych plam w obszarze zastosowania, jakim jest szeroko pojęte zarządzanie, oraz zaproponowano możliwe kierunki dalszych badań.
\end{abstract}

Słowa kluczowe: ekonofizyka, model grawitacyjny, gry mniejszościowe

DOI: $10.17512 /$ znpcz.2017.4.1.06

\section{Wprowadzenie}

Ekonofizyka to dziedzina naukowa z pogranicza ekonomii, finansów, matematyki finansowej oraz fizyki statystycznej, zajmująca się ekonomicznymi układami złożonymi. Podstawową ideą ekonofizyki jest to, że zarówno w fizyce statystycznej, jak w ekonomii oraz na rynkach finansowych pojedyncze elementy sytemu złożonego ${ }^{1}$ oddziałują na siebie, co skutkuje zauważalnymi zmianami $\mathrm{w}$ całym układzie. Dzięki tej obserwacji wiele zjawisk zachodzących w gospodarce, jak i na rynkach finansowych, można opisać, wykorzystując prawa i zasady znane z fizyki. Modele ekonomiczne wykorzystujące podstawowe prawa fizyki funkcjonują już od lat 60. XX wieku. Najczęściej stosowanymi w ekonomii zasadami są: prawo grawitacji, pierwsza i druga zasada dynamiki, a ostatnio fizyka statystyczna oraz mechanika kwantowa.

W kontekście powyższych rozważań sformułowany został cel niniejszego artykułu, którym jest:

CG: Identyfikacja praktycznego zastosowania modeli ekonofizycznych $w$ różnych obszarach i zakresach wspomagania zarzadzania.

W zamiarze osiągnięcia celu głównego w pracy skoncentrowano się na odpowiedzi na następujące pytanie badawcze:

PB: $W$ jakich obszarach $i w$ jakim zakresie procesu zarzadzania stosowanie modeli ekonofizycznych już jest lub $z$ dużym prawdopodobieństwem może być efektywne?

\footnotetext{
${ }^{1}$ System złożony - system składający się z wielkiej liczby części, które w sposób nieprosty wchodzą ze sobą w interakcje.
} 
Ze względu na ograniczoną objętość artykułu odwołano się do dwóch modeli ekonofizycznych, tj. modelu grawitacyjnego (nawiązującego do prawa ciążenia powszechnego) oraz modelu gier mniejszościowych (nawiązującego do praw fizyki statystycznej). Wyniki zrealizowanego badania zostały zaprezentowane poniżej.

\section{Modele grawitacyjne w badaniach ekonomiczno-przestrzennych}

W fizyce przyjmuje się, że grawitacja, czyli ciążenie powszechne, jest to właściwość materii polegająca na wzajemnym przyciąganiu się ciał materialnych. Za twórcę teorii grawitacji, którą określa się czasami jako mechanikę newtonowską, uważa się I. Newtona. W mechanice newtonowskiej (klasycznej) masę punktu materialnego określa się jako dodatnią wielkość skalarną, będącą miarą bezwładności tego punktu. Przyjmuje się także, że masa obiektu nie zależy od stanu ruchu (jest niezmienna) oraz nie ulega zmianie podczas zachodzących w niej dowolnych procesów. Jest to tak zwana zasada zachowania masy.

Prawo powszechnego ciążenia, zwane również prawem grawitacji, mówi, że każde dwa punkty materialne przyciągają się wzajemnie za pomocą siły wprost proporcjonalnej do iloczynu mas obu punktów, a odwrotnie proporcjonalnej do kwadratu odległości pomiędzy nimi. Co można wyrazić wzorem:

$$
F=G \frac{m_{1} m_{2}}{d^{2}}
$$

gdzie:

$m_{1} m_{2}$ - masy punktów materialnych,

$d$ - odległość między tymi punktami,

$G$ - współczynnik proporcjonalności,

$F$ - siła grawitacji lub siła ciążenia.

Z punktu widzenia zastosowań ekonomicznych ważniejsze od grawitacji jest tzw. pole grawitacyjne. Pozwala ono określić wielkość i kierunek siły grawitacyjnej działającej na znajdujące się $\mathrm{w}$ polu grawitacyjnym ciała posiadające masę. Wielkością charakteryzującą pole grawitacyjne jest natężenie pola grawitacyjnego, które wyraża się jako:

$$
\gamma=\frac{M}{d^{2}}
$$

gdzie $M$ jest masą źródła.

W ekonomii wykorzystuje się także pojęcie energii potencjalnej opisanej wzorem:

$$
E_{p}=-G \frac{M m}{d}
$$

Próby zastosowania modeli grawitacyjnych $w$ badaniach ekonomiczno-przestrzennych podjęto na początku XX wieku. Jednak oficjalnie za prekursora tych badań uważa się demografa J.Q. Stewarta, który zdefiniował pojęcie siły demograficznej, jako odpowiednika energii potencjalnej, oraz potencjału demograficznego, jako odpowiednika potencjału pola grawitacyjnego. Właściwe modele grawitacyjne stosowane $\mathrm{w}$ naukach ekonomicznych powstały w latach 60 . XX 
wieku. Odpowiednikami punktów materialnych stały się ośrodki takie jak: miasta, centra handlowe itp., zaś ekonomicznym odpowiednikiem słowa „grawitacja” stała się „interakcja”. Jeden z najwcześniejszych modeli miał postać:

$$
I_{i j}=G \frac{M_{i} M_{j}}{d_{i j}^{c}}
$$

gdzie:

$I_{i j}$ - interakcja (oddziaływanie) pomiędzy obszarami $i$ oraz $j$,

$M_{i} M_{j}-$,masy” dwóch obszarów, które mogą być mierzone liczbą ludności,

$d_{i j}$ - odległość pomiędzy obszarem $i$ oraz $j$,

$G$ - odpowiednik stałej ciążenia określanej w ekonomii mianem kalibracji,

$c$ - wykładnik potęgi odległości.

Należy podkreślić, że wzór 4 jest analogiczny do 1 .

Jednostkami (masami) mogą być: kraj, region gospodarczy, województwo, miasto. Za miarę masy, w zależności od rozważanego problemu, przyjmuje się liczbę gospodarstw domowych, liczbę miejsc konsumpcyjnych, liczbę magazynów i sklepów, wielkość powierzchni sprzedażowej i magazynowej, liczbę łóżek w szpitalach, nakłady gazet i czasopism, liczbę ludności itp. Odległość z kolei mierzy się w kilometrach, może to być również czas dojazdu lub iloczyn ceny i czasu podróży. Kalibracja odnosi się do modelu i określa się ją w ten sposób, aby rozważany model był dobrze dopasowany do danych empirycznych (Heckman, Leamer (ed.) 2001, s. 3653-3703).

Zagadnień związanych z modelami grawitacyjnymi jest wiele. Na przykład: w latach 30. XX wieku jeden z badaczy rynku - W.J. Reilly (Reilly 1931) - zają się problemem wyznaczenia ilości dostarczanych towarów produkowanych w dwóch konkurujących ze sobą metropoliach małemu miastu położonemu między nimi. Innym wartym odnotowania modelem, określającym mechanizmy wymiany handlowej, jest model zaprezentowany po raz pierwszy ponad pół wieku temu, przez holenderskiego ekonomistę Jana Tinbergena (1962). Odwołując się do prawa powszechnego ciążenia, zaproponował on grawitacyjny model handlu, pomiędzy dwoma krajami w postaci opisanej następującym równaniem:

$$
O_{i j}=G \frac{P N B_{i} P N B_{j}}{d_{i j}}
$$

gdzie:

$O_{i j}$ - obroty handlowe między krajami $i$ oraz $j$,

$P N B_{i} P N B_{j}$ - produkt narodowy brutto kraju $i$ i $j$,

$d_{i j}$ - odległość geograficzna między krajami $i$ oraz $j$,

$G$ - odpowiednik stałej ciążenia określanej w ekonomii mianem stałej kalibracji.

Zgodnie z powyższym równaniem wielkość dwustronnych obrotów handlowych $O_{i j}$ między krajami $i$ oraz $j$ jest dodatnio skorelowana $\mathrm{z}$ wielkością gospodarek obu krajów, wyrażoną poziomem ich produktów narodowych brutto $P N B_{i}$ oraz $P N B_{j}$, a ujemnie skorelowana z odległością pomiędzy nimi $d_{i j}$ (Drzewoszewska, Pietrzak, Wilk 2013, s. 187-202). 
Przy konstrukcji modelu grawitacyjnego, opisującego relacje międzynarodowe, ważną kwestią jest określenie czynników wpływających na „siłę przyciągania” krajów oraz określenie odległości pomiędzy partnerami handlowymi (Gómez-Herrera 2013, s. 1087-1111). Jednym z czynników determinujących obroty handlowe jest wielkość krajów, która może być mierzona za pomocą produktu krajowego brutto (PKB), kombinacją produktu narodowego brutto (PNB) i liczby ludności (Linneman 1966, s. 10-45), jak również wartością PKB przypadającego na jednego mieszkańca (Carrère 2006, s. 223-247). W modelach grawitacyjnych handlu międzynarodowego odległość geograficzna jest czynnikiem osłabiającym siłę przyciągania, ponieważ zwiększa czas oraz koszty transportu.

Próbę identyfikacji czynników wymiany handlowej z wykorzystaniem powyższego modelu podjęto w pracy (Pietrzak, Łapińska 2014). Następnie przeprowadzono estymację tych parametrów modelu, które uznano za istotnie determinujące poziom obrotów handlowych pomiędzy krajami Unii Europejskiej, a zaliczono do nich: wielkość PKB, poziom rozwoju gospodarczego mierzonego PKB per capita oraz bezpośrednie inwestycje zagraniczne. Potwierdzono również ujemną korelację odległości geograficznej między krajami a wielkością ich wzajemnej wymiany. Autorzy doszli również do wniosku, że rozszerzenie Unii Europejskiej o nowe kraje pozytywnie wpływa na wzrost eksportu zachodzący pomiędzy nimi.

Udoskonaleniem modeli grawitacyjnych są modele atrakcyjności handlowej oraz potencjału ${ }^{2}$. Wśród nich na szczególną uwagę zasługuje model Huffa (Huff 1963, s. 81-89). Jest to model probabilistyczny wykorzystywany w przestrzennych analizach geomarketingowych, który opracowany został przez D.L. Huffa (1962). Dotyczy on zagadnienia „ciążenia” konsumentów do ośrodków handlowych na badanym obszarze. Według L.D. Huffa czas podróży i atrakcyjność ośrodka handlowego są czynnikami wpływającymi na zachowanie konsumenta i mogą służyć do prognozowania wyboru miejsca zakupów. Wzór na model Huffa wygląda następująco:

gdzie:

$$
\operatorname{Prob}_{i j}=\frac{\frac{M_{j}}{T_{i j}}}{\sum_{j}^{n} \frac{M_{j}}{T_{i j}}}
$$

$\operatorname{Prob}_{i j}$ - prawdopodobieństwo, że pojedynczy konsument zamieszkały w regionie $i$-tym skorzysta z zakupów w rejonie $j$,

$M_{j}$ - wielkość „masa” placówki (wyrażona np.: w m², ilości kas, wielkości asortymentu itp.), z której korzysta konsument $j$,

$T_{i j}$ - czas niezbędny na przemieszczenie się konsumenta z regionu $i$ do placówki $j$.

\footnotetext{
${ }^{2}$ Potencjał - interpretowany jest jako miara oddziaływania elementów wchodzących w skład rozpatrywanego systemu. Potencjał określa intensywność oddziaływania między elementami systemu nie tylko jako zmienna zależna od wielkości elementu (lub ich cech), ale również od ich względnej lokalizacji.
} 
W praktyce gospodarczej model ten jest dość często wykorzystywany. Jeden z przykładów zaprezentowany został w pracy (Pan-Jin i in. 2011, s. 1543-1550), gdzie model Huffa użyty został do prognozowania wielkości sprzedaży sklepu. Autorzy badania zmodyfikowali model o takie zmienne jak koszty reklamy i promocji czy rozpoznawalność marki. Wyniki badania przeprowadzonego na próbie czterech sklepów handlowych okazały się satysfakcjonujące, a wskaźnik błędu prognozy kształtował się na poziomie $5 \%$. Zaznaczono jednak, że nie powinny być one uogólniane ze względu na zbyt małą próbę badawczą. Inne modele grawitacyjne odnoszące się do ekonomicznych interakcji przestrzennych zaproponowali: M. Cadwallader (Cadwallader 1981, s. 275-284), T. Stanley i M. Sewall (Stanley, Sewall 1976, s. 48-53), P.D. Converse (Converse 1949, s. 379-384), P. Krugman (Krugman 1991, s. 483-499).

Grawitacja nie jest jedyną zasadą fizyki, która z powodzeniem wykorzystywana jest w ekonomii i naukach społecznych. Na uwagę zasługuje również fizyka statystyczna i oparty na niej model gry mniejszościowej, o czym będzie mowa w kolejnym podrozdziale.

\section{Wybrane zastosowania gier mniejszościowych}

W modelu gry mniejszościowej (GM) uczestnicy rynku, których jest bardzo wielu (np. continuum), kupują i sprzedają papiery wartościowe. Handel odbywa się na bazie analizy fluktuacji cen walorów giełdowych i docierających na rynek informacji. Jeżeli większość uczestników rynku zamierza nabyć papiery wartościowe, to wówczas opłaca się sprzedać i na odwrót. $Z$ reguły gracze $\mathrm{z}$ grupy mniejszościowej wygrywają. Wszyscy uczestnicy rynku podejmują decyzje, wykorzystując pewne „wzorce informacji”. W związku z tym w grze mniejszościowej wyróżnia się trzy typy graczy:

- graczy wywołujących szum informacyjny i podejmujących przypadkowe decyzje;

- producentów zachowujących się w sposób deterministyczny;

- spekulantów.

Działania tych trzech grup kumulują się, prowadząc do zmian jakościowych całego układu, podobnie jak ma to miejsce w makroskopowych układach fizycznych, gdzie obserwowane są oddziaływania elektromagnetyczne w skali makro. Model MG, odniesiony do rynków finansowych, umożliwia precyzyjną ilustrację alokacji kapitału i instrumentów finansowych przy pomocy reguł fizyki statystycznej. Fizyka statystyczna zajmuje się makroskopowymi układami fizycznymi, składającymi się z atomów oraz cząstek i bada ich zachowania. Mogą to być: ciała stałe, ciecze, gazy, a także organizmy żywe o różnorodnej postaci i składzie. Układy takie dążą do stanu równowagi, który nie wykazuje tendencji do zmiany w czasie, z wyjątkiem przypadkowych fluktuacji, przy czym pewne stany układu makroskopowego są bardziej prawdopodobne niż inne. Potencjał, równanie stanu, zasady zachowania - to charakterystyczne elementy wywodzącego się z fizyki zestawu powiązanych ze sobą terminów, które to terminy są wykorzystywane podczas modelowania zjawisk ekonomicznych z wykorzystaniem gier mniejszościowych. Nadmienić należy, że oddziaływania i interakcje pomiędzy uczestnikami rynku wzorowane są na 
oddziaływaniach fizycznych, a ich badaniem zajmuje się ekonofizyka (Drabik 2012, s. 3-6).

Inicjatorem badań nad grą mniejszościową był W. Brian Arthur, który w swojej pracy zdefiniował tzw. El Farol Bar Problem (Arthur 1994, s. 406-411). Składa się ona z $N$ uczestników, określanych mianem inwestorów lub uczestników rynku. Grę mniejszościową opisać można w następujący sposób:

1. Przyjmuje się, że gra na rynku finansowym jest grą o sumie niezerowej, z liczbą inwestorów $\mathrm{N}(\mathrm{N} \rightarrow \infty)$.

2. W dowolnym momencie gry $t(t=1,2, \ldots)$ każdy uczestnik rynku może, ale nie musi, podjąć jedną z dwóch decyzji: kupna lub sprzedaży, która wyrażona jest jako $a_{i}(t)=+1$ lub $a_{i}(t)=-1$.

3. Wypłata (zysk) $i$-tego inwestora określa równanie:

$$
\begin{gathered}
g_{i}(t)=-a_{i}(t) A(t) \\
\text { gdzie: } A(t)=\sum_{j=1}^{N} a_{j}(t)
\end{gathered}
$$

Wartość $A(t)$ oznacza różnicę pomiędzy liczbą inwestorów, którzy podjęli decyzję o sprzedaży, a liczbą inwestorów, którzy zdecydowali się na kupno akcji w czasie $t$. Jeśli $A(t)>0$, wygrywają inwestorzy, którzy podjęli decyzję $a_{i}(t)=-1$, tracą zaś ci wybierający $a_{i}(t)=+1$.

4. Strategia $s_{i}(t)$ inwestora $i \mathrm{w}$ czasie $t(i=1, \ldots, N ; t=1,2, \ldots)$ jest oceniana na podstawie informacji $\{1, \ldots \mu, \ldots \mathrm{P}\}$ uzyskanych przez uczestnika ryku $\mathrm{w}$ trakcie przebiegu gry. Zdefiniowana jest ona w następujący sposób: $s_{i}(t):\{1, \ldots \mu, \ldots \mathrm{P}\} \rightarrow\{-1 ;+1\}$. W przedstawionym przypadku informacja uwzględnia zarówno historię gry, jak i ciąg przeszłych decyzji mniejszościowych i większościowych inwestorów oraz pewne informacje otrzymywane z zewnątrz.

5. Biorąc pod uwagę otrzymane informacje, jak i „zdolności adaptacyjne” poszczególnych uczestników rynku, zysk $i$-tego inwestora wyrazić można w następujący sposób:

$$
\begin{gathered}
g_{i}(t)=-a_{i}(t)_{s_{i}(t), i}^{\mu(t)} A^{\mu(t)}(t) \\
\text { gdzie: } A^{\mu(t)}(t)=\sum_{j=1}^{N} a_{\mathrm{s}_{\mathrm{j}}(\mathrm{t}), \mathrm{j}}^{\mu(\mathrm{t})}(t) \\
\text { gdzie: } a_{i}(t) \rightarrow a_{i}(t)_{s_{i}(t), i}^{\mu(t)} i \quad A(t) \rightarrow A^{\mu(t)}(t)
\end{gathered}
$$

6. Celem każdego uczestnika rynku jest maksymalizacja zysku $g_{i}(t)(i=1, \ldots, N)$ na dowolnym etapie gry $t$.

Przedstawione zagadnienie można rozwiązać na wiele sposobów. Przykładowo: Challet (Challet, Marsili, Zhang 2000, s. 284-315) i Mosetti (Mosetti, Challet, 
Zhang 2005, s. 529-542), modelując rynki finansowe z wykorzystaniem gry mniejszościowej, koncentrują się na badaniu funkcji $A(t)$. Zauważają, że wariancja $\sigma^{2}(t)=\langle A(t)\rangle$ jest miarą rozkładu środków finansowych na rynku, a równanie: $\alpha=\frac{\mathrm{P}}{\mathrm{N}}$ poziomu informacji. Gdy $\alpha \gg 1$, na rynku jest zbyt wiele informacji, a podejmowane przez inwestorów decyzje są losowe. Kiedy $\alpha \rightarrow 1$, do gry dołącza więcej inwestorów, a napływające na rynek informacje wykorzystywane są efektywniej. Jeśli $\alpha$ osiągnie swoje minimum:

$$
\left(\alpha=\frac{7}{20}\right)
$$

zachowanie uczestników rynku może zostać porównane do przebiegu zjawisk krytycznych w fizyce statystycznej.

Prawdopodobieństwo dokonania określonej decyzji przez każdego inwestora ustala się w następujący sposób:

$$
\operatorname{Prob}\left\{a_{i}(t)= \pm 1\right\}=\frac{e^{ \pm g_{i}(t)}}{e^{g_{i}(t)}+e^{-g_{i}(t)}}
$$

W modelu gry mniejszościowej nie jest możliwe „precyzyjne” określenie ceny akcji w chwili $(t)$ i $(t+1)$. Zakłada się, że zmiana ceny waloru kształtowana jest przez ilość zleceń kupna i sprzedaży. Jeżeli przewagę osiągają inwestorzy chcący sprzedać akcje, cena ich spada. Cena będzie rosła przy przewadze kupujących. W grze mniejszościowej różnicę pomiędzy liczbą inwestorów, którzy podjęli decyzję o sprzedaży akcji, a liczbą inwestorów, którzy zdecydowali się na ich kupno w czasie $t$ obliczamy ze wzoru:

$$
A(t)=\sum_{j=1}^{N} a_{j}(t)
$$

Wartość zmiany ceny waloru zależy od jej wrażliwości na zmianę ilości zleceń kupna i sprzedaży. Określa się to mianem głębokości rynku. Dlatego też badanie stóp zwrotu w grach mniejszościowych sprowadza się do założenia liniowej zależności:

$$
r_{(t)}=\log \left(p(t+1)-\log (p(t))=\frac{A(t)}{\lambda}\right.
$$

gdzie $\lambda$ jest parametrem mierzącym wrażliwość ceny na zmianę ilości zleceń kupna i sprzedaży.

Przedstawiony model gier mniejszościowych z powodzeniem wykorzystywany jest na rynkach finansowych. Wspomnieć należy badania prowadzone przez K. Wawrzyniaka (Wawrzyniak 2011, s. 83-85), które przewidywały kolejne zmiany cen pięciu akcji z największym wpływem na indeks WIG20. Wskaźnik sukcesu prognozy kierunku zmiany cen wynosił od $53 \%$ do $70 \%$, w zależności od przyjętych parametrów modelu. Z kolei Challet, Marsili i Zhang (Challet, Marsili, Zhang 2001, s. 514-524) wykorzystali MG jako prosty model rynków finansowych oparty o graczy, który jest w stanie odwzorowywać tzw. fakty stylizowane, takie jak: nietypowy rozkład stóp zwrotu czy zjawisko grupowania zmienności. 
Gry mniejszościowe wykorzystane zostały również w modelowaniu ruchu samochodowego. Badania we wspomnianym zakresie prowadzone były m.in. przez (Kuen 2002; Chmura, Pitz 2004; Galib, Moser 2011, s. 519-526). W pracach badano zależności pomiędzy wielkością grupy podejmującej decyzje mniejszościowe a osiąganymi przez nią korzyściami w postaci szybszego dotarcia do miejsca podróży. Analizowano, jakie informacje są najbardziej przydatne w podejmowaniu decyzji o wyborze tras oraz możliwości interakcji pomiędzy najbliższymi uczestnikami gry, polegające na naśladowaniu poruszającego się najszybciej uczestnika gry. Okazało się, że umiarkowane naśladowanie sprzyja zmniejszeniu czasu podróży pomiędzy punktami. Mało efektywnym rozwiązaniem było natomiast naśladowanie najlepszego uczestnika przez wszystkich pozostałych graczy. Najbardziej przydatnymi informacjami przy podejmowaniu decyzji o wyborze trasy podróży były: całkowity czas przejazdu oraz aktualna średnia prędkość poruszania się na trasie.

Kolejny model inspirowany grą mniejszościową i wykorzystywany w biologii i epidemiologii zaproponowali (Vardavas, Breban, Blowe 2007). Składa się on z $N$ osób, niekomunikujących się ze sobą i podejmujących decyzję o szczepieniach. Co roku osoby te samodzielnie decydują, czy szczepić się przeciwko grypie, czy też nie, przy użyciu skutecznej szczepionki nieposiadającej skutków ubocznych. Osoby w modelu charakteryzują się dwoma cechami biologicznymi (adaptacyjnością i pamięcią), które wykorzystują podczas podejmowania decyzji o szczepieniach. W modelu podjęto próbę zbadania wpływu poszczególnych szczepień na decyzje dotyczące szczepień przeciwko epidemiologii grypy, jak również wpływu epidemiologii grypy na decyzje dotyczące szczepień na poziomie indywidualnym. Zbadano, czy program szczepień bez zachęt jest w stanie objąć taki poziom populacji, który uniemożliwia pojawienie się epidemii grypy. Oceniono również, jak systemy motywacyjne, w postaci m.in. darmowej szczepionki, wpływają na poziom szczepień. Analizie poddano również potencjalny wpływ programu szczepienia całej rodziny na częstość występowania epidemii. Okazało się, że jeżeli decyzja o szczepieniu całej rodziny podejmowana jest przez głowę rodziny, to częstotliwość występowania poważnych epidemii wzrasta. Wynika to z faktu, że nasilenie i częstość występowania epidemii są funkcją liczby osób, które samodzielnie podejmują decyzje odnośnie szczepienia. Przekazanie decyzji o szczepieniu głowie rodziny zmniejsza liczbę niezależnych decydentów, co skutkuje częstszym pojawieniem się dużych wahań osób nieszczepionych. Stwierdzono, że program szczepień rodziny zwiększył częstotliwość poważnych epidemii, a na szczepienia częściej decydują się osoby o długotrwałym zaangażowaniu w program, które ostatnimi latami nie chorowały na grypę.

Związki pomiędzy grą mniejszościową a rynkiem aukcji badali B.C. Lustosa oraz D.O. Cajueiro (Lustosa, Cajueiro 2010). W swojej pracy wprowadzili zmodyfikowany model GM, w którym jedynymi uczestnikami gry, którzy posiadają informację o tym, czy byli w grupie mniejszościowej, czy większościowej, są ci, którzy wybrali się do przysłowiowego baru EL Farol. Pozostali uczestnicy z różnym prawdopodobieństwem mogą otrzymać tę informację od pozostałych graczy, którzy faktycznie byli w barze, lub z mediów. Autorzy wykazują, że jeżeli dostęp 
do informacji jest ograniczony, gra nie może toczyć się wokół optymalnego podziału pomiędzy grupę mniejszościową i większościową. Pojawia się możliwość arbitrażu, a największe korzyści osiągają gracze posiadający informację. Z drugiej strony jednak istnieje punkt krytyczny, powyżej którego ilość obecnych w barze graczy jest $w$ stanie przekazać informację osobom nieobecnym. Autorzy pracy zauważyli, że dynamika gry w dobry sposób odzwierciedla dynamikę aukcji towarów, w szczególności samochodów na rynku w Brazylii.

\section{Możliwości wykorzystania modeli ekonofizycznych w zarządzaniu}

W poszukiwaniu obszarów zastosowania modeli ekonofizycznych i odpowiedzi na zdefiniowane pytanie badawcze opracowano Tabele 1. Zawiera ona obszary zastosowań omawianych modeli wraz z białymi plamami, gdzie zastosowanie modeli jest bardzo małe lub nie istnieje. Zawiera ona również odniesienia do źródeł prac badawczych, które reprezentują wyszczególnione obszary zastosowań.

Tabela 1. Obszary zastosowań modeli ekonofizycznych

\begin{tabular}{|c|c|c|}
\hline Rodzaj modelu & Gry mniejszościowe & Model grawitacyjny \\
\hline Aukcje & $\begin{array}{l}\text { B.C. Lustosa, D.O. Cajueiro, } 2010 . \\
\text { Q. Zeng, B.R. Davis, D. Abbot, } 2007 .\end{array}$ & - \\
\hline Rynek kapitałowy & \begin{tabular}{|c|} 
F.D.R. Bonnet, D. Abbott, 2010. \\
D. Challet, M. Marsili, Y.C. Zhang, 2013. \\
A. Krause, 2009. \\
K. Wawrzyniak, 2011. \\
K. Wawrzyniak, W. Wiślicki, 2011. \\
\end{tabular} & $\begin{array}{l}\text { J. Ferwerda, M. Kattenberg, } \\
\text { H.H. Chang, B. Unger, L. Groot, } \\
\text { J.A. Bikker, } 2013 \text {. }\end{array}$ \\
\hline Transport & $\begin{array}{l}\text { S.M. Galib, I. Moser, } 2011 . \\
\text { T. Chmura, T. Pitz, } 2006 . \\
\text { T. Chmura, T. Pitz, } 2004 . \\
\end{array}$ & $\begin{array}{c}\text { G. De Jong, I. Vierth, L. Tavasszy, } \\
\text { M. Ben-Akiva, 2013. } \\
\text { J. Khadaroo, B. Seetanah, } 2008 \text {. } \\
\end{array}$ \\
\hline $\begin{array}{l}\text { Handel } \\
\text { międzynarodowy }\end{array}$ & - & $\begin{array}{l}\text { M.B. Pietrzak, J. Łapińska, } 2014 . \\
\text { B.H. Baltagi, P.H. Egger, } \\
\text { M. Pfaffermayr, } 2014 . \\
\text { D. Novy, 2013. }\end{array}$ \\
\hline Handel lokalny & - & $\begin{array}{l}\text { K. Pan-Jin, K. Wanki, C. Won- } \\
\text { Ki, Y. Myoung-Kil, } 2011 . \\
\text { K. Migdał-Najman, A. Mudza, } 2009 . \\
\text { S. Wiśniewski, } 2016 .\end{array}$ \\
\hline $\begin{array}{l}\text { Biologia } \\
\text { (podejmowanie } \\
\text { decyzji) }\end{array}$ & R. Vardavas, R. Breban, S. Blower, 2007. & - \\
\hline Demografia & - & D. Bunea, 2012. \\
\hline Zarządzanie & H. Huang, Y. Cai, H. Xu, H. Yu, 2017. & - \\
\hline
\end{tabular}

Źródło: Opracowanie własne 
Modele grawitacyjne oraz GM wykorzystane są w wielu obszarach zastosowań, co zaprezentowano w Tabeli 1, lecz możliwości ich implementacji są ściśle powiązane z prawami fizyki, z których się wywodzą.

Modele grawitacyjne oprócz wymienionych powyżej zastosowań mogą być wykorzystane $\mathrm{w}$ wielu innych obszarach. Jednym z nich jest edukacja. Uczelnia, podejmując decyzję o uruchomieniu nowego kierunku studiów, powinna oszacować potencjalną liczbę zainteresowanych kandydatów na ten kierunek. W tym celu wykorzystać można model Huffa. Analogicznie jak ma to miejsce przy prognozowaniu wielkości obrotów nowo otwieranych sklepów, i tutaj uwzględnić należy takie czynniki jak: prestiż, bliskość konkurencji czy wielkość miasta i potencjalną liczbę interesantów. Podobny problem, poruszający kwestię migracji studentów, przedstawiono w pracy J. Cullinana i J. Duggana (Cullinan, Duggan 2016 s. 294-314). Model grawitacyjny jest dość często eksploatowany w literaturze, służy do określenia lokalizacji planowanego lotniska, stacji kolejowych czy przystanków przesiadkowych (Khosravi, Akbari Jokar 2017 s. 28-38). Zaadaptowany może zostać w logistyce magazynowej, w celu określenia optymalnej lokalizacji stanowisk produkcyjnych, czy w marketingu, przy szacowaniu zasięgu kampanii reklamowych.

Możliwości zastosowań jest bardzo wiele. Na Rysunku 1 przedstawiono intensywność wykorzystania modelu grawitacyjnego w wybranych aspektach zarządzania.

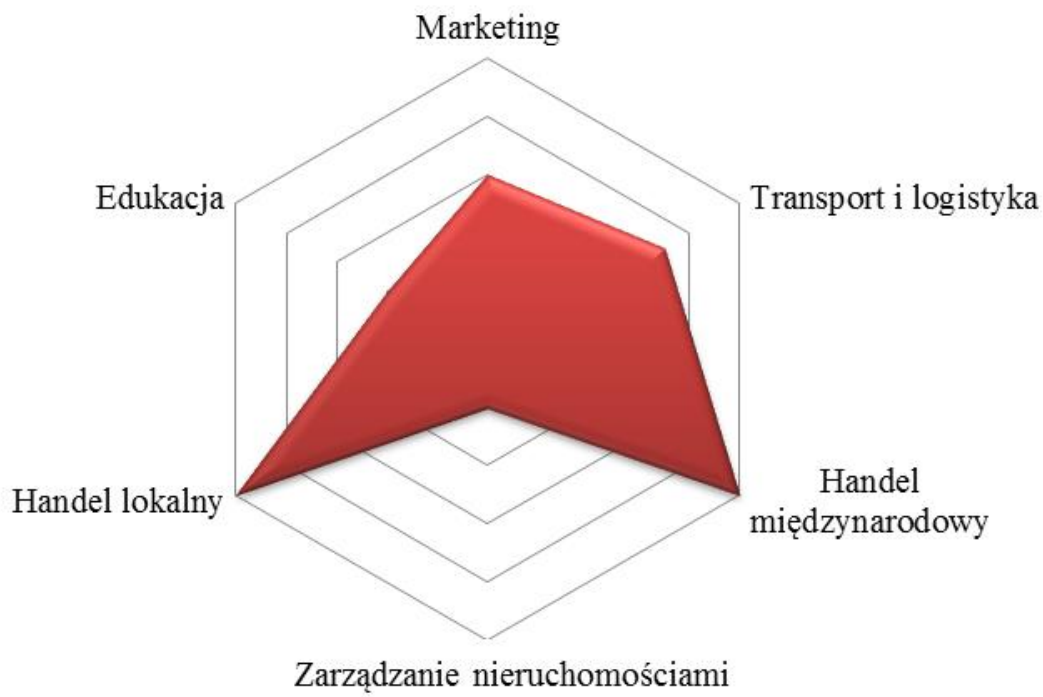

Rysunek 1. Obszary zastosowań modelu grawitacyjnego

Źródło: Opracowanie własne

Wykres opracowany został na podstawie sporządzonego przeglądu literatury tematu z wykorzystaniem przeglądarki Google Scholar służącej do przeszukiwania baz danych zawierających publikacje naukowe. 
Mimo popularności wykorzystania modelu grawitacyjnego w szacowaniu wymiany handlowej na szczeblu międzynarodowym, jak i przy określaniu lokalizacji handlowych na rynku lokalnym zauważyć należy powtarzający się problem. Model ten pozwala jedynie na przybliżone określenie szacowanych wartości. Jest to uproszony obraz rzeczywistości gospodarczej, uniemożliwiający ujęcie i odwzorowanie skomplikowanych powiązań, występujących pomiędzy wszystkimi czynnikami determinującymi szacowaną wartość. W omawianej grupie modeli należy określić dodatkowo stałą kalibracji ${ }^{3}$, która pozwala na odniesienie teoretycznego modelu do realiów gospodarczych. Jej wyznaczenie wymaga wielu badań i eksperymentów, co bezpośrednio wpływa na mniejszą popularność modelu grawitacyjnego w takich obszarach jak marketing, edukacja czy produkcja. Dlatego obecnie, wraz z rozwojem narzędzi analitycznych, coraz częściej wykorzystuje się zaawansowane techniki komputerowe oparte na metodach sztucznej inteligencji (np. sieci neuronowe) i logikę rozmytą (umożliwiającą zwiększenie tolerancji na niepewność i niepełność danych analitycznych) w celu prognozowania i symulowania zjawisk gospodarczych.

W przypadku GM badania podążać powinny w kierunku wykorzystania zależności w zachowaniu uczestników gry od liczby dostępnych strategii. Okazuje się, że gdy liczba graczy w stosunku do liczby strategii osiąga wartość krytyczną (w przypadku GM wynoszącą $\frac{7}{20}$ ), może dochodzić do zachowań stadnych. Analogię tę można wykorzystać przykładowo w badaniu nad reakcjami tłumów w czasie organizacji imprez masowych. Wystarczy liczbę strategii zastąpić liczbą miejsc ewakuacyjnych, by określić, jaka ich liczba pozwala na bezpieczną ewakuację w chwili zagrożenia. Kolejnym elementem, na który warto zwrócić uwagę, jest kooperacja pomiędzy uczestnikami gry. Pełni ona kluczową rolę w grze mniejszościowej. Kiedy gracze współdziałają, to maksymalizują korzyści z gry. Wynika to z faktu, że gdy grupa mniejszościowa osiąga maksymalną wielkość zbliżoną do połowy populacji, to maksymalna liczba uczestników osiąga korzyść. Analogicznie dzieje się na przykład w handlu, gdzie na rynku mamy do czynienia z duopolem. Jeżeli przedsiębiorstwa wbrew prawu dojdą do porozumienia i zaczną współpracować, fluktuacja ich udziałów w rynku spadnie, co pozwoli na osiąganie wyższych zysków aniżeli w sytuacji, gdyby miały ze sobą rzeczywiście konkurować.

W grach mniejszościowych, jak to było już wspominane, bierze udział wielu graczy, często określanych mianem agentów, którzy podejmują decyzję na podstawie dostępnych informacji. Zauważyć tutaj należy analogię do metod sztucznej inteligencji (SI), w której również wykorzystywani są agenci. Zarówno w GM jak i w SI zadaniem agentów jest rozwiązywanie zagadnień o charakterze rozproszonym lub złożonym obliczeniowo (Bond, Gasser 2014). Agenci wykorzystywani są również w programowaniu, a tak zwane technologie agentowe są ważnym elementem w budowie społeczeństwa informacyjnego (Niedbał 2015). Z tego też względu nadal istnieje szerokie pole zastosowań dla GM, a w szczególności w tych obszarach, gdzie badane są zachowania populacji (Młodzianowski, Młodzianowski 2018).

\footnotetext{
${ }^{3}$ Kalibracja - czynność polegająca na doborze parametrów modelu w sposób umożliwiający osiągnięcie wyników symulacji zbliżonych do zbioru danych określających zachowanie obiektu rzeczywistego.
} 
Ewidentnie nieeksploatowanymi obszarami zastosowań GM, tak jak w przypadku modeli grawitacyjnych są: edukacja oraz szeroko pojęte zarządzanie. $\mathrm{W}$ aspekcie zarządzania należy zwrócić uwagę na analogię pomiędzy przewidywaniem zachowania inwestorów, do czego często wykorzystywane są MG, a zarządzaniem ryzykiem na rynku finansowym. Umiejętność przewidywania zachowań inwestorów w znaczący sposób wpływać może na obniżenie poziomu ryzyka podejmowanych decyzji. Gry mniejszościowe zaadaptowane mogą zostać również w zarządzaniu produkcją i zasobami. Dzięki wbudowanemu systemowi samouczących się graczy, podejmujących decyzje na podstawie przeszłych zdarzeń i dostępnych zasobów, symulować można alokację zasobów i ich optymalne wykorzystanie w ramach przedsiębiorstwa (Zhang i in. 2012, s. 63-68).

\section{Podsumowanie}

Zaprezentowanie modeli fizycznych wykorzystywanych w ekonomii oraz zaproponowanie nowych możliwości ich wykorzystania pozwoliło na realizację zdefiniowanego celu oraz udzielenie odpowiedzi na sformułowane pytania badawcze. Podstawowym wnioskiem wynikającym z pracy jest to, że istnieje szerokie pole zastosowań metod fizycznych $\mathrm{w}$ różnych zakresach zastosowań ekonomicznych, zarządczych i finansowych. Za pomocą modeli ekonofizycznych efektywnie badać można m.in.: zmiany demograficzne, prognozy sprzedaży, wielkość obrotów handlowych pomiędzy państwami czy postępowanie w trakcie trwania epidemii. Metody fizyczne swoje zastosowanie znajdą również na rynkach finansowych. Istnieje wiele modeli rynków finansowych, m.in.: model gier mniejszościowych, w których do odzwierciedlenia zachowania inwestorów z powodzeniem wykorzystywane są analogie występujące $\mathrm{w}$ oddziaływaniach elektromagnetycznych. Jednak mimo licznych zastosowań wspomnianych modeli i istniejącego pola do dalszych badań wydaje się, że są one coraz częściej wypierane przez modele oparte na sieciach neuronowych oraz innych metodach sztucznej inteligencji. Podczas gdy w opinii autora są dla nich solidną alternatywą i uzupełnieniem, ponieważ charakteryzuje je mniejsza złożoność obliczeniowa, co pozwala uniknąć efektu tzw. „,czarnej skrzynki". Warto też zaznaczyć, że w pracy zaprezentowano jedynie wybrane modele ekonofizyczne. W rzeczywistości jest ich o wiele więcej, a obszary ich zastosowań sięgają daleko poza nauki ekonomiczne.

\section{Literatura}

1. Akerlof G.A. (1970), The Market for „Lemons”. Quality Uncertainty and The Market Mechanism, „Quarterly Journal of Economics”, Vol. 84(3), s. 488-500. DOI: 10.2307/ 1879431

2. Arthur W.B. (1994), Inductive Reasoning, Bounded Rationality, and the Bar Problem, „American Economic Review”, Vol. 84, s. 406-411.

3. Baltagi B.H., Egger P.H., Pfaffermayr M. (2014), Panel Data Gravity Models of International Trade, „CESifo Working Papers”, No. 4616, http://www.cesifo-group.de/ DocDL/cesifo1_wp4616.pdf. 
4. Bond A.H., Gasser L. (2014), Readings in Distributed Artificial Intelligence, Morgan Kaufmann, San Fransisco.

5. Bonnet F.D.R., Abbott D. (2010), Can a Minority Game Follow Real Market Dynamics?, „In Fluctuation and Noise Letters”, Vol. 1, s. 107-128.

6. Bornholdt S. (2001), Expectation Bubbles in a Spin Model of Markets: Intermittency from Frustration across Scales, „International Journal of Modern Physics C”, Vol. 12, No. 5, s. 667-674. DOI: 10.1142/S0129183101001845

7. Bunea D. (2012), Modern Gravity Models of Internal Migration. The Case of Romania, „Theoretical and Applied Economics”, Vol. 19, No. 4(569), s. 127-144.

8. Cadwallader M. (1981), Towards a Cognitive Gravity Model: The Case of Consumer Spatial Behaviour, „Regional Studies”, Vol. 15(4), s. 275-284. DOI: 10.1080/095952381001 85281

9. Carrère C. (2006), Revisiting the Effects of Regional Trade Agreements on Trade Flows with Proper Specification of the Gravity Model, „European Economic Review”, Vol. 50(2), s. 223-247. DOI: 10.1016/j.euroecorev.2004.06.001

10. Challet D., Marsili M., Zhang Y.C. (2000), Modeling Market Mechanism with Minority, „Physica A: Statistical Mechanics and its Applications”, Vol. 276, s. 284-315. DOI: 10.1016/S0378-4371(99)00446-X

11. Challet D., Marsili M., Zhang Y.C. (2001), Stylized Facts of Financial Markets and Market Crashes in Minority Games, „Physica A. Statistical Mechanics and its Applications”, Vol. 294(3), s. 514-524. DOI: 10.1016/S0378-4371(01)00103-0

12. Challet D., Marsili M., Zhang, Y.C. (2013), Minority Games: Interacting Agents in Financial Markets, OUP Oxford, Oxford.

13. Chmura T., Pitz T. (2004), Minority Game: Experiments and Simulations of Traffic Scenarios, Bonn Econ Discussion Papers 23, Universität Bonn, Bonn.

14. Chmura T., Pitz T. (2006), Successful Strategies in Repeated Minority Games, „Physica A Statistical Mechanics and its Applications”, Vol. 363(2), s. 477-480. DOI: 10.1016/j.physa. 2005.12.053

15. Converse P.D. (1949), New Laws of Retail Gravitation, „Journal of Marketing”, Vol. 14(3), s. 379-384. DOI: $10.2307 / 1248191$

16. Cullinan J., Duggan J. (2016), A School-Level Gravity Model of Student Migration Flows to Higher Education Institutions, „Spatial Economic Analysis”, Vol. 11, s. 294-314. DOI: 10.1080/17421772.2016.1177195

17. De Jong G., Vierth I., Tavasszy L., Ben-Akiva M. (2013), Recent Developments in National and International Freight Transport Models within Europe, „Transportation”, February, Vol. 40(2), s. 347-371. DOI: 10.1007/s11116-012-9422-9

18. Drabik E. (2012), Wybrane modele mechanizmów rynkowych oparte na prawach fizyki statystycznej i mechaniki kwantowej, „Optimum Studia Ekonomiczne”, nr 2(56), s. 3-20.

19. Drabik E., Młodzianowski P. (2016), Some Remarks about Financial Market Modelling Using a Minority Game Approach, „Economics World”, Vol. 4(5), s. 216-223. DOI: 10.17265/2328-7144/2016.05.002

20. Drzewoszewska N., Pietrzak M.B., Wilk J. (2013), Grawitacyjny model przeptywów handlowych między krajami Unii Europejskiej w dobie globalizacji, „Roczniki Kolegium Analiz Ekonomicznych", nr 30, s. 187-202.

21. Ferwerda J., Kattenberg M., Chang H.H., Unger B., Groot L., Bikker J.A. (2013), Gravity Models of Trade-Based Money Laundering, „Applied Economics”, Vol. 45(22), s. 3170-3182. DOI: 10.2139/ssrn.1943473

22. Galib S.M., Moser I. (2011), Road Traffic Optimisation Using an Evolutionary Game, [w:] Proceedings of the 13th Annual Conference Companion on Genetic and Evolutionary Computation, New York, s. 519-526. DOI: 10.1145/2001858.2002043 
23. Gómez-Herrera E. (2013), Comparing Alternative Methods to Estimate Gravity models of Bilateral Trade, „Empirical Economics”, Vol. 44(3), s. 1087-1111. DOI: 10.1007/s00181012-0576-2

24. Heckman J.J., Leamer E. (ed.) (2001), Handbook of Econometrics, North Holland.

25. Huang H., Cai Y., Xu H., Yu H. (2017), A Multiagent Minority-Game-Based DemandResponse Management of Smart Buildings Toward Peak Load Reduction, „IEEE Transactions on Computer-Aided Design of Integrated Circuits and Systems”, Vol. 36(4), s. 573-585. DOI: 10.1109/TCAD.2016.2571847

26. Huff D.L. (1963), A Probabilistic Analysis of Shopping Centre Trade Areas, „Land Economics", Vol. 38(1), s. 81-90.

27. Khadaroo J., Seetanah B. (2008), The Role of Transport Infrastructure in International Tourism Development: A Gravity Model Approach, „Tourism Management”, Vol. 29(5), s. 831-840. DOI: 10.1016/j.tourman.2007.09.005

28. Khosravi S., Akbari Jokar M.R. (2017), Facility and Hub Location Model Based on Gravity Rule, „Computers \& Industrial Engineering”, Vol. 109, s. 28-38. DOI: 10.1016/j.cie.2017. 04.005

29. Krause A. (2009), Evaluating the Performance of Adapting Trading Strategies with Different Memory Lengths, [w:] Corchado E., Yin H. (eds.), Intelligent Data Engineering and Automated Learning - IDEAL 2009, International Conference on Intelligent Data Engineering and Automated Learning, Lecture Notes in Computer Science, Vol. 5788, Springer, Berlin, Haidelberg, s. 711-718. DOI: 10.1007/978-3-642-04394-9_87

30. Krugman P. (1991), Increasing Returns and Economic Geography, „Journal of Political Economy", Vol. 99(3), s. 483-499.

31. Kuen L. (2002), Studies on the Minority Game and Traffic Flow Models, Chinese University of Hong Kong, Hong Kong.

32. Linneman H. (1966), An Econometric Study of International Trade Flows, North-Holland, Amsterdam

33. Lustosa B.C., Cajueiro D.O. (2010), Constrained Information Minority Game: How Was the Night at El Farol?, „Physica A. Statistical Mechanics and its Applications”, Vol. 389(6), s. 1230-1238. DOI: 10.1016/j.physa.2009.11.034

34. Migdał-Najman K., Mudza A. (2009), Zastosowanie modelu grawitacji względnej Huffa $w$ analizie rynku wielkopowierzchniowych placówek handlowych, „Marketing i Rynek”, R. 16, nr 3, s. 27-34.

35. Młodzianowski P., Młodzianowski D. (2018), Identification of Areas of Econophysical Models Application, „Economics World”, Vol. 6(1), s. 34-44. DOI: 10.17265/2328-7144/ 2018.01.004

36. Mosetti G., Challet D., Zhang Y.C. (2005), Heterogenous Time Scales in Minority Game, „Physica A. Statistical Mechanics and its Applications”, Vol. 365, s. 529-542. DOI: 10.1016/j.physa.2005.09.069

37. Niedbał R. (2015), Rola technologii agentowych $w$ budowie spoteczeństwa informacyjnego, „Zeszyty Naukowe Politechniki Częstochowskiej. Zarządzanie”, nr 17, s. 112-122.

38. Novy D. (2013), Gravity Redux: Measuring International Trade Costs with Panel Data, „Economic Inquiry”, Vol. 51(1), s. 101-121. DOI: 10.1111/j.1465-7295.2011.00439.x

39. Pan-Jin K., Wanki K., Won-Ki C., Myoung-Kil Y. (2011), Using New Huff Model for Predicting Potential Retail Market in South Korea, „African Journal of Business Management", Vol. 5(5), s. 1543-1550.

40. Pietrzak M.B., Łapińska J. (2014), Zastosowanie modelu grawitacji do identyfikacji czynników determinujacych przepływy handlowe w Unii Europejskiej, „Przegląd Statystyczny”, R. 61, z. 1, s. 65-77.

41. Reilly W.J. (1931), The Law of Retail Gravitation, William J. Reilly, New York. 
42. Stanley T.J., Sewall M.A. (1976), Image Inputs to a Probabilistic Model: Predicting Retail Potential, „Journal of Marketing”, Vol. 40(3), s. 48-53. DOI: 10.2307/1249994

43. Vardavas R., Breban R., Blower S. (2007), Can Influenza Epidemics Be Prevented by Voluntary Vaccination?, „PLoS Computational Biology”, May, Vol. 3(5). DOI: 10.1371/ journal.pcbi.0030085

44. Wawrzyniak K. (2011), On Phenomenology, Dynamics and some Applications of the Minority Game, praca doktorska, PAN.

45. Wawrzyniak K., Wiślicki W. (2011), Minority Games as a Predictor of Future Signal Changes, [w:] Submitted to European Conference on Complex Systems ECCS2011.

46. Wiśniewski S. (2016), Dostępność mieszkańców województwa łódzkiego do sklepów wielkopowierzchniowych, „Acta Universitatis Lodziensis. Folia Geographica Socio-Oeconomica”, nr 23, s. 25-38. DOI: 10.18778/1508-1117.23.02

47. Zeng Q., Davis B.R., Abbott D. (2007), Reverse Auction: The Lowest Unique Positive Integer Game, „Fluctuation and Noise Letters”, Vol. 7(4), s. L439-L447. DOI: 10.1142/ S0219477507004069

48. Zhang C., Wu W., Huang H., Yu H. (2012), Fair Energy Resource Allocation by Minority Game Algorithm for Smart Buildings, [w:] Design, Automation \& Test in Europe Conference \& Exhibition (DATE), Dresden, s. 63-68. DOI: 10.1109/DATE.2012.6176434

\title{
IDENTIFICATION OF PRACTICAL AREAS OF ECONOPHYSICAL MODELS APPLICATION
}

\begin{abstract}
The article presents results of reflections on practical applications of econophysical models in different fields and areas of the management support. It discusses the problem of gravity models and minority games used in economic and social sciences. Their applications in areas such as trade, transport, analysis of financial market fluctuations, or decision making are presented. An attempt is made to identify missing pieces in the area of broadly understood management, and possible directions for further research are suggested.
\end{abstract}

Keywords: econophysics, gravity model, minority game 